\title{
PERBANDINGAN JUMLAH KUMAN PADA LALAPAN YANG DIJUAL DI RUMAH MAKAN DAN PEDAGANG KAKI LIMADI JALAN A. P. PETTARANI KOTA MAKASSAR
}

Comparison Of Number Of Numbers In Flies That Are Sold In Eat House And Limadi Foot

Traders A. P. Pettarani Kota Makassar

St. Mu'tamirah ${ }^{1}$ dan Amryl ${ }^{2}$

${ }^{1,2}$ Akademi Kesehatan Lingkungan Muhammadiyah Makassar

*)stmutamirah@gmail.com

\begin{abstract}
Indonesian salad are vegetables usually served along with Indonesian cuisine. Lalapan commonly eaten with rice and side dishes. Lalapan are usually served in a raw state. Lalapan commonly used include green beans, basil, cabbage, chili sauce, and cucumber. Lalapan are found sold in restaurants and street vendors. The purpose of this study was to determine differences in the number of bacteria in fresh vegetables sold in restaurant and Street Vendors in A.P. Pettarani Street Makassar. The method used in this study was a descriptive observational and determination of the number of bacteria while using the Total Plate Count. The results of the examination of 10 samples of lalapan were sold at restaurant and street vendors 7 samples showed that lalapans have a number of bacteria exceeds $1 \times 10^{5}$ while the three of them have met the requirements. The number of bacteria in lalapan sold in restaurant long beans by type ie the number of germs $19655 \times 10^{2}$, the number of germs basil $4105 \times 10^{2}$, the number of germs cabbage $14465 \times 10^{2}$, the number of germs sauce $425 \times 10^{2}$, and cucumber with a number of germs $39795 \times 10^{2}$. and for Street Vendors ie the number of germs beans $65 \times 103$, the number of germs basil $12415 \times 10^{2}$, the number of germs cabbage $582 \times 10^{3}$, the number of germs sauce $515 \times 10^{2}$, and cucumber with number of germs $608 \times 10^{3}$. From these resultsit can be concludedthat thenumber ofbacteria inlalapansold inrestauranthigher than thelalapansoldatstreet vendors. It isinfluencedbyseveral factors such asfood ingredients, shelf lifeof food, sothe foodstorage area, and thehygieneof foodhandlers. Seeingthese circumstancesit may be advisableto furtherimprove theimplementation offoodhygienesanitationinrestaurantandstreet vendors.
\end{abstract}

Keywords $\quad$ : Lalapan, Restaurants, Street Vendors, Number of Bacteria.

\section{ABSTRAK}

Lalapan adalah sayur-sayuran yang biasa disajikan beserta masakan Indonesia. Lalapan biasa dimakan bersama nasi dan lauk-pauk. Sayur-sayuran ini biasanya dihidangkan dalam keadaan mentah. Sayur-sayuran yang biasa digunakan antara lain kacang panjang, kemangi, kubis, sambal, dan timun. Lalapan ini banyak ditemukan dijual di rumah makan maupun pedagang kaki lima.Tujuan dari penelitian ini adalah untuk mengetahui perbedaan jumlah kuman pada lalapan yang dijual di Rumah Makan dan Pedagang Kaki Lima di Jln. A.P. Pettarani kota Makassar. Metode yang digunakan dalam penelitian ini adalah deskriptif observasional sedangkan penentuan jumlah kumannya menggunakan metode Total Plate Count. Hasil pemeriksaan terhadap 10 sampel lalapan yang dijual di Rumah Makan dan Pedagang Kaki Lima didapatkan hasil bahwa 7 sampel lalapan memiliki jumlah kuman melebih $1 \times 10^{5}$ sedangkan tiga diantaranya telah memenuhi persyaratan. Jumlah kuman pada lalapan yang dijual di Rumah Makan berdasarkan jenisnya yaitu kacang panjang dengan jumlah kuman $19.655 \times 10^{2}$, kemangi dengan jumlah kuman $4.105 \times 10^{2}$, kubis dengan jumlah kuman $14.465 \times 10^{2}$, sambal dengan jumlah kuman $425 \times 10^{2}$, serta timun dengan jumlah kuman $39.795 \times 10^{2}$. Dan untuk Pedagang Kaki Lima yaitu kacang panjang dengan jumlah kuman $65 \times 10^{3}$, kemangi dengan jumlah kuman $12.415 \times 10^{2}$, kubis dengan jumlah kuman $582 \times 10^{3}$, sambal dengan jumlah kuman $515 \times 10^{2}$, dan timun dengan jumlah kuman $608 \times 10^{3}$.Dari hasil penelitian tersebut dapat disimpulkan bahwa jumlah kuman pada lalapan yang dijual di Rumah Makan lebih tinggi dibandingkan dengan lalapan yang dijual di Pedagang Kaki Lima. Hal ini dipengaruhi oleh beberapa faktor antara lain bahan makanan, waktu simpan makanan, tempat penyimpanan makanan jadi, dan hygiene penjamah makanan. Melihat keadaan tersebut maka dapat disarankan untuk lebih meningkatkan penerapan hygiene sanitasi makanan di Rumah Makan dan Pedagang Kaki Lima.

Kata Kunci : Lalapan, Rumah Makan, Pedagang Kaki Lima, Jumlah Kuman.

\section{PENDAHULUAN}

Abad 21 adalah abad yang ditandai dengan kecanggihan teknologi yang menuntut manusia untuk memiliki mobilitas yang tinggi. Mobilitas yang tinggi ini telah membawa perubahan kebiasaan dalam masyarakat salah satunya adalah kebiasaan makan di rumah berubah menjadi makan di luar.

Perusahaan riset

Nielsen menyebutkan sekitar 44 persen masyarakat dunia, termasuk Indonesia, makan di luar rumah satu hingga tiga kali dalam seminggu
(Tempo, 2009). Kebiasaan makan diluar ditunjang dengan ketersediaan rumah makan, kaki lima, dan menu yang beragam.

Salah satu menu yang digemari oleh masyarakat adalah menu lalapan. Lalapan adalah makanan yang berupa sayuran segar yang disajikan tanpa melalui proses pemasakan. Makanan yang tidak melalui proses pemasakan biasanya berdampak negatif terhadap kesehatan manusia. Salah satu dampak yang paling sering terjadi adalah keracunan makanan. 
Di Indonesia, kasus keracunan makan cukup sering terjadi. Pada tahun 2010, tercatat 132 Kasus dan 13 Insiden Keracunan Makanan/ Keracunan Pangan terjadi dan terlaporkan di Sentra Informasi Keracunan Nasional Badan Pengawas Obat dan Makanan RI (MF. Isnaini, 2009). Salah satu keracunan makanan yang pernah terjadi di Indonesia adalah kasus keracunan makanan yang menimpa 100 orang karyawan PT CGN Central Georgette Nusantara (Fajrin, 2008). Untuk Sulawesi Selatan sendiri, Badan Pengawas Obat dan Makanan (BPOM) menempatkan Provinsi Sulawesi Selatan di urutan kedua dalam keracunan makanan setelah Jawa Barat (Anonim, 2009). Seperti pada kasus keracunan yang terjadi di Kab. Bulukumba, Pangkep, Gowa, dan Sidrap (Zaenab, 2008).

Kasus keracunan makanan ini cukup sering terjadi di kota Makassar. Dinas Kesehatan kota Makassar mencatat rentan waktu antara tahun 2006 sampai 2011 terjadi 12 kasus keracunan makanan yang menimpa warga kota Makassar dengan 413 korban (Dinas Kesehatan Kota Makassar).

Lalapan sendiri sangat berpotensi untuk menyebabkan keracunan makanan. Ada beberapa faktor yang membuat lalapan dapat menyebabkan keracunan makanan yaitu residu pestisida, pencucian yang tidak sempurna, air pencuci, kontaminasi bakteri patogen, dan senyawa racun alami (Made A, 2012)

Di kota Makassar, lalapan sangat mudah ditemukan dijual baik di rumah makan maupun pedagang kaki lima. Tempat penjualan ini sangat berpengaruh terhadap kualitas makanan terutama untuk kualitas bakteriologis. Hal ini dapat dilihat dari data Depkes RI tahun 1984 menyebutkan menurut jenis Tempat Pengelolaan Makanan (TPM), didapatkan kontaminasi bakteri patogen seperti E. Coli lebih tinggi pada pedagang kaki lima jika dibandingkan dengan rumah makan (Oggy S, 2012).

Disepanjang jalan A. P. Pettarani ada sekitar 24 pedagang kaki lima yang menjual lalapan. Mobilitas yang tinggi disekitar jalan A. $P$. Pettarani ini sangat memungkinkan untuk mengkontaminasi makanan yang dijual oleh pedagang kaki lima. Tentu hal ini akan berbeda jika dibandingkan dengan rumah makan. Salah satu hal yang membedakan adalah hygiene sanitasi makanan yang diterapkan di rumah makan dan pedagang kaki lima tentulah berbeda. Misalnya persyaratan kesehatan lingkungan bangunan, ketersediaan fasilitas sanitasi, serta penerapan hygienen perorangan dan food safety di rumah makan lebih baik jika dibandingkan dengan kaki lima.

Berdasarkan uraian diatas, maka penulis tertarik untuk melakukan penelitian tentang "Studi Perbandingan Jumlah Kuman Pada Lalapan Yang Dijual Di Rumah Makan Dan Pedagang Kaki Lima Di Jalan A. P. Pettarani Kota Makassar"

\section{METODE \\ Lokasi Penelitian}

Lokasi pengambilan sampel lalapan yaitu salah satu rumah makan dan pedagang kaki lima yang ada di Jln. A.P. Pettarani kota Makassar. Sedangkan untuk pemeriksaan sampelnya dilakukan di laboratorium Akademi Kesehatan Lingkungan Muhammadiyah Makassar.

\section{Populasi dan Sampel}

Populasi dalam penelitian ini adalah semua lalapan yang dijual di rumah makan dan pedagang kaki lima yang berada di JIn. A. P.Pettarani Kota Makassar Tahun 2014.

Sampel dalam penelitian ini adalah lalapan yang dijual di salah satu rumah makan dan pedagang kaki lima yang ada di JIn. A.P. Pettarani kota Makassar. Pengambilan sampel lalapan dilakukan dengan menggunakan metode representatif atau yang dianggap mewakili. Jumlah sampel dari penelitian ini adalah 10 sampel berdasarkan jenis lalapan yang dijual yaitu kacang panjang, kemangi, kubis, timun, dan sambal.

\section{Pengumpulan Data}

Data primer dari penelitian ini diperoleh melalui observasi langsung ke lapangan dan uji laboratorium yang dilaksanakan di Laboratotium Akademi Kesehatan Lingkungan Muhammadiyah Makassar.

Data sekunder dari penelitian ini diperoleh dari kajian pustaka dari beberapa buku dan literatur lain yang berkaitan dengan penelitian ini.

\section{Analisa Data}

Data hasil pemeriksaan laboratorium terhadap jumlah kuman pada lalapan yang dijual di rumah makan dan pedagang kaki lima di Jln. A.P. Pettarani kota Makassar kemudia disajikan dalam bentuk tabel, 
kemudian dianalisis secara deskriftip dan diuraikan secara narasi.

\section{HASIL}

Berdasarkan penelitian yang dilakukan tentang perbandingan jumlah kuman pada lalapan yang dijual di rumah makan dan pedagang kaki lima di Jln. A. P. Pettarani kota Makassar, maka di bawah ini penulis akan menguraikan hasil pemeriksaan laboratorium dan hasil pengamatan langsung di lapangan sebagai berikut :

1. Semua jenis lalapan yang dijual di rumah makan di Jln. A.P. Pettarani kota Makassar belum memenuhi persyaratan jumlah kuman pada lalapan yaitu $1 \times 10^{5}$ kecuali sambal yang didasarkan pada Peraturan Kepala BPOM No.HK.00.06.1.52.4011 tahun 2009 dan SNI No. 7388 tahun 2009 tentang batas maksimum cemaran mikroba dalam pangan.

2. Dari semua jenis lalapan yang dijual di pedagang kaki lima, jumlah kuman pada kacang panjang dan sambal tidak melapaui batas maksimum cemaran mikroba dalam pangan sesuai dengan Peraturan Kepala BPOM No.HK.00.06.1.52.4011 tahun 2009 dan SNI No. 7388 tahun 2009 yaitu $1 \times 10^{5}$. Selain kacang panjang dan sambal kesemuanya belum memenuhi persyaratan untuk jumlah kuman pada makanan.

Tabel 1

Hasil pemeriksaan jumlah kuman pada lalapan yang dijual di rumah makan, Juni

\section{4}

\begin{tabular}{|c|c|c|c|c|}
\hline $\begin{array}{l}\mathbf{N} \\
\mathbf{0}\end{array}$ & $\begin{array}{l}\text { Jenis } \\
\text { Lalapan }\end{array}$ & $\begin{array}{c}\text { ALT } \\
\text { (Koloni/gr) } \\
\end{array}$ & Keterangan & $\begin{array}{c}\text { Batas } \\
\text { Maksimum } 1 \\
\times 10^{5} \\
\text { koloni/gr } \\
\end{array}$ \\
\hline 1 & $\begin{array}{l}\text { Kacang } \\
\text { Panjang }\end{array}$ & $65 \times 10^{3}$ & MS & \multirow{5}{*}{$\begin{array}{l}\text { Perarturan } \\
\text { Kepala } \\
\text { BPOM RI No. } \\
\text { HK. } \\
00.06 .1 .52 .40 \\
11 \text { dan SNI } \\
\text { No. } 7388 \\
\text { Tahun } 2009\end{array}$} \\
\hline 2 & $\begin{array}{l}\text { Kemang } \\
\mathrm{i}\end{array}$ & $\begin{array}{c}12.415 \mathrm{x} \\
10^{2} \\
\end{array}$ & TMS & \\
\hline 3 & Kubis & $582 \times 10^{3}$ & TMS & \\
\hline 4 & Sambal & $515 \times 10^{2}$ & MS & \\
\hline 5 & Timun & $608 \times 10^{3}$ & TMS & \\
\hline
\end{tabular}

Tabel 2

Hasil pemeriksaan jumlah kuman pada lalapan yang dijual di pedagang kaki lima, Juni 2014

\begin{tabular}{|c|c|c|c|c|}
\hline $\begin{array}{l}\mathrm{N} \\
\mathbf{0}\end{array}$ & $\begin{array}{c}\text { Jenis } \\
\text { Lalapa } \\
\text { n }\end{array}$ & $\begin{array}{c}\text { ALT } \\
\text { (Koloni/ } \\
\text { gr) }\end{array}$ & $\begin{array}{l}\text { Keterang } \\
\text { an }\end{array}$ & $\begin{array}{c}\text { Batas } \\
\text { Maksimum 1 } \\
\text { x } 10^{5} \\
\text { koloni/gr }\end{array}$ \\
\hline 1 & $\begin{array}{l}\text { Kacan } \\
\mathrm{g} \\
\text { Panjan } \\
\mathrm{g}\end{array}$ & $\begin{array}{c}19.655 x \\
10^{2}\end{array}$ & TMS & \multirow{5}{*}{$\begin{array}{c}\text { Perarturan } \\
\text { Kepala } \\
\text { BPOM RI No. } \\
\text { HK. } \\
00.06 .1 .52 .40 \\
11 \text { dan SNI } \\
\text { No. } 7388 \\
\text { Tahun } 2009\end{array}$} \\
\hline 2 & $\begin{array}{l}\text { Keman } \\
\text { gi }\end{array}$ & $\begin{array}{c}4.105 x \\
10^{2}\end{array}$ & TMS & \\
\hline 3 & Kubis & $\begin{array}{c}14.465 x \\
10^{2}\end{array}$ & TMS & \\
\hline 4 & Samba & $425 \times 10^{2}$ & MS & \\
\hline 5 & Timun & $\begin{array}{c}39.795 x \\
10^{2}\end{array}$ & TMS & \\
\hline
\end{tabular}

Tabel 3

Perbandingan kualitas bahan makanan yang digunakan di rumah makan dan pedagang kaki lima

\begin{tabular}{|l|c|c|c|c|c|c|}
\hline \multirow{2}{*}{$\begin{array}{l}\text { Jenis } \\
\text { Lalapan }\end{array}$} & \multicolumn{5}{|c|}{ Kualitas Bahan Makanan } \\
\cline { 2 - 7 } & Kesegaran & \multicolumn{2}{c|}{ Warna } & \multicolumn{2}{c|}{ Bentuk } \\
\cline { 2 - 7 } & $\mathbf{R M}$ & PKL & $\mathbf{R M}$ & PKL & RM & PKL \\
\hline $\begin{array}{l}\text { Kacang } \\
\text { Panjang }\end{array}$ & Tidak & Segar & Berubah & $\begin{array}{c}\text { Tidak } \\
\text { Berubah }\end{array}$ & Baik & Baik \\
\hline Kemangi & Segar & Segar & $\begin{array}{c}\text { Tidak } \\
\text { Berubah }\end{array}$ & $\begin{array}{c}\text { Tidak } \\
\text { Berubah }\end{array}$ & Utuh & Utuh \\
\hline Kubis & Tidak & Segar & Berubah & $\begin{array}{c}\text { Tidak } \\
\text { Berubah }\end{array}$ & $\begin{array}{c}\text { Tidak } \\
\text { Utuh }\end{array}$ & Utuh \\
\hline \multirow{2}{*}{ Timun } & Tidak & Segar & Berubah & $\begin{array}{c}\text { Tidak } \\
\text { Berubah }\end{array}$ & $\begin{array}{c}\text { Tidak } \\
\text { Baik }\end{array}$ & Baik \\
\hline
\end{tabular}

Tabel 4

Perbedaan waktu simpan lalapan yang dijual di rumah makan dan pedagang kaki lima

\begin{tabular}{|c|c|}
\hline $\begin{array}{c}\text { Tempat Pengolahan } \\
\text { Makanan }\end{array}$ & $\begin{array}{c}\text { Waktu Simpan } \\
\text { Lalapan (Jam) }\end{array}$ \\
\hline Rumah Makan & 8-10 Jam \\
\hline Pedagang Kaki Lima & 10-24 Jam \\
\hline
\end{tabular}

Tabel 5

Perbedaan tempat penyimpanan lalapan yang dijual di ruma makan dan pedagang kaki lima

\begin{tabular}{|c|c|}
\hline $\begin{array}{c}\text { Tempat Pengolahan } \\
\text { Makanan }\end{array}$ & $\begin{array}{c}\text { Kondisi Tempat } \\
\text { Penyimpanan }\end{array}$ \\
\hline Rumah Makan & Tidak memiliki penutup \\
\hline Pedagang Kaki Lima & Memiliki penutup \\
\hline
\end{tabular}


3. Berdasarkan hasil pemeriksaan laboratorium, diketahui bahwa dari lima jenis lalapan yang diperiksa, tiga diantaranya yaitu kacang panjang, kubis, dan timun yang dijual di rumah makan memiliki jumlah kuman yang lebih tinggi dibandingkan dengan yang dijual di pedagang kaki lima. Hal ini dipengaruhi beberapa hal yaitu bahan makanan, waktu simpan dan kondisi tempat penyimpanan makanan jadi.

\section{PEMBAHASAN}

Dari beberapa penelitian didapatkan hasil bahwa tingkat kontaminasi mikroba pada makanan berbeda menurut tempat pengolahannya. Penelitan Djaja (2003) pada tiga tempat pengolahan makanan menyimpulkan bahwa pedagang kaki lima berisiko 3,5 kali lipat terhadap terjadinya kontaminasi makanan dibandingkan dengan usaha jasaboga, restoran dan rumah makan (Febria A, dkk, 2009).

Dari hasil pemeriksaan laboratorium yang dilakukan pada lalapan yang dijual di rumah makan dan pedagang kaki lima di Jln. A. P. Pettarani dengan parameter jumlah kuman, didapatkan hasil bahwa jumlah kuman pada lalapan yang dijual di rumah makan lebih tinggi jika dibandingkan dengan yang dijual di rumah makan. Hal dapat dipengaruhi oleh beberapa hal, yaitu :

1. Bahan Makanan

Kualitas bahan makanan yang baik dapat dilihat melalui ciri-ciri fisik dan mutunya dalam hal ini, bentuk, warna, kesegaran, bau dan lainnya (Kusmayadi, 2008 dalam J. Sinaga 2011). Dari hasil pengamatan, didapatkan hasil bahwa kualitas bahan makanan yang digunakan di pedagang kaki lima lebih baik dibandingkan dengan rumah makan. Hal ini dapat dilihat pada kesegaran dan warna makanan yang digunakan oleh pedagang kaki lima lebih baik dibandingkan dengan rumah makan. Selain itu ditemukan bekas gigitan dan bintik-bintik hitam pada bahan yang digunakan oleg rumah makan. Kondisi bahan makanan yang digunakan oleh rumah makan ini tidak sesuai dengan persyaratan hygiene sanitasi makanan untuk sayuran yaitu harus dalam keadaan segar, utuh, tidak layu, tidak berubah warna, dan tidak ada bekas gigitan hewan (J. Sinaga, 2011).
2. Penyimpanan Makanan Jadi Makanan jadi harus disimpan pada tempat yang tidak terjangkau tikus, serangga, dan bintang pengganggu lainnya (J. Sinaga 2011). Dalam menyimpan makanan jadi ada beberapa hal yang perlu diperhatikan yaitu waktu simpan, tempat, dan suhu penyimpanan makana jadi.

a. Waktu simpan makanan ini sangat menentukan banyaknya jumlah kuman dalam makanan. $\mathrm{Hal}$ ini sesuai dengan penelitian (Djaja 2003) yang menyatakan bahwa waktu penyimpanan dan penyajian (6-7 jam) akan memberi cukup kesempatan bagi bakteri untuk berkembang biak menjadi 1 (satu) juta dalam waktu 6 (enam) jam (Febria A, dkk, 2009). Waktu simpan lalapan pada rumah makan lebih lama dibandingkan dengan pedagang kaki lima.

b. Lalapan yang dijual oleh pedagang kaki lima disimpan pada wadah tertutup sedangkan di rumah makan tidak. Menurut persyaratan hygiene dan sanitasi makanan, wadah untuk menyimpan makanan jadi harus memilki penutup untuk mencegah terjadinya kontaminasi baik oleh udara, debu, ataupun serangga. Makanan yang disimpan pada wadah yang tidak memiliki penutup sangat rentan terhadapa kontaminasi udara, debu, maupun serangga., udara, debu, maupun serangga dapat mengkontaminasi makanan baik secara langsung maupun tidak langsung Menurut (Anwar,1987 dalam Asmiati,2010).

c. Baik di rumah makan maupun pedagang kaki lima, lalapan ini disimpan pada suhu kamar yaitu sekitar $25^{\circ} \mathrm{C}-30^{\circ} \mathrm{C}$ yang sangat baik untuk pertumbuhan bakteri.

Hal ini berbeda dengan persyaratan hygiene sanitasi makanan yang mengatakan bahwa makanan harus diusahakan untuk disimpan pada suhu dibawah $10^{\circ} \mathrm{C}$ atau diatas $60^{\circ} \mathrm{C}$ karena suhu tersebut sangat berbahaya untuk pertumbuhan bakteri (J. Sinaga, 2011).

3. Pengolahan Makanan

Pengolahan makanan ini $\begin{array}{r}\text { sangat } \\ \text { dalam }\end{array}$
besar peranannya


mengkontaminasi makanan. Menurut Sapers 2001, kontaminasi mikroba pada produk pertanian termasuk sayuran yang akan dijadikan lalapan dapat terjadi pada beberapa titik diantaranya adalah pada saat pengolaahan. Salah satu hal yang sangat penting untuk diperhatikan dalam mengolah makanan adalah penjamah makanan.

Dari hasil pengamatan di rumah makan dan pedagang kaki lima, dapat diketahui bahwa penerapan hygiene pada penjamah makanan masih sangat rendah. Pada saat menjamah makanan, mereka tidak mencuci tangan sebelum menjamah makanan, menyentuh makanan dengan menggunakan tangan kosong, serta penjamah makanan berbicara saat sedang menjamah makanan.

Hal ini tidak memenuhi persyaratan hygiene sanitasi makanan bagi penjamah makanan yang diharuskan untuk mencuci tangan setiap kali hendak menangi makanan, menjamah makanan harus memakai alat/perlengkapan atau alas tangan (J. Sinaga, 2011). Berbicara saat menjamah makanan serta menjamah makanan dengan tangan kosong dapat mengkontaminasi makanan baik secara langsung maupun tidak langsung (Anwar, 1987 dalam Asmiati 2010).

Rumah Makan, tidak ada pembagian tugas yang jelas untuk penjamah makanan. Tidak ada orang yang ditugaskan khusus untuk mengolah, mengantar, maupun menyajikan makanan. Semua karyawan bisa menjadi pengolah maupun penyaji. Hal ini dapat membuat kontaminasi pada makanan menjadi tinggi karena semakin banyak orang yang menyentuh makanan makan kontaminasinya akan semakin tinggi.

\section{KESIMPULAN dan SARAN}

Berdasarkan hasil penelitian dan pembahasan, dapat disimpulkan bahwa jumlah kuman pada lalapan yang dijual di rumah makan memiliki jumlah kuman yang lebih tinggi dibandingkan dengan lalapan yang dijual di pedagang kaki lima. Oleh karena disarankan baik kepada pemerintah maupun pengelola rumah makan dan pedagang kaki lima untuk meningkatkan pengetahuan kepada penjamah makanan baik di pedagang kaki lima maupun rumah makan melalui penyuluhan atau pelatihan bagi penjamah makana mengenai higiene dan sanitasi pengolahan makanan serta pendampingan untuk menumbuhkan kesadaran dan melakukan pemantauan sehingga dapat meningkatkan kualitas makanan yang dijual serta memperhatikan ketentuan enam prinsip hygiene sanitasi makanan.

\section{DAFTAR PUSTAKA}

Anonim. 2009. Bukan Sekedar Makan. http://www.tempo.co/read/news/2009/04/14/108170283/Bukan-Sekedar Makan.Diakses tanggal 02 April 2014.

2009.Sulsel urutan kedua kasus keracunan makanan.http://www.antarasulawesiselatan.com/berita/12210/sulsel-urutan-kedua-kasus-keracunan-makanan.Diakses tanggal 02 April 2014

Asmiati.2010.Studi Kualitas Bakteriologis Roti Bread Talk yang Diperdagangkan di Mall Ratu Indah Makassar. Makassar: AKL Muhammadiyah Makassar. (KTI tidak diterbitkan).

Fajrin.2008.Kejadian Luar Biasa.http://keslingmks.files.wordpress.com/2008/12/fajrin-klb.doc. Diakses tanggal 02 April 2014

Febria Agustina, Rindit Pembayun, Fatmalina Febry.2009. Higiene Sanitasi Pada Pedagang Makanan Jajanan Traditional di Lingkungan Sekolah Dasar di Kelurahan Demang Lebar Daun Palembang Tahun 2009.http://eprints.unsri.ac.id/64/3/Abstrak8.pdf.Diakses tanggal 09 Juni 2014 
J.Sinaga.2011. Hygiene Sanitasi Makanan. repository.usu.ac.id/bitstream/123456789/28057/4/Chapter\%20Il.pdf. Universitas Sumatera Utara. Diakses tanggal 18 April 2014.

Made Astawan.2014.Mana Lebih Baik, Lalapan atau Sayuran Dimasak?. http://health.kompas.com/read/2014/04/11/0755332/mana.lebih.baik.lalapan.atau.sayuran. dimasak. Diakses tanggal 02 April 2014

MF. Isnaini.2009.Tentang Keracunan Makanan/Keracunan Pangan. http://indonesiabisasehat.blogspot.com/2012/04/tentang-keracunan-makanankeracunan.html.diakses tanggal 02 April 2014

Oggy Satria Saputra.2012.Deteksi Bakteri Patogen pada Makanan di Pedagang Kaki Lima Kecamatan Gubeng Kota Surabaya.http://ijtmh.org/arsip-koleksi/80-september-2012/85deteksi-bakteri-patogen-pada-makanan-di-pedagang-kaki-lima-kecamatan-gubeng-kotasurabaya.html.Fakultas Kedokteran UniversitasAirlangga.Diakses tanggal 24 April 2014

Sapers, GM. 2001. Efficacy of Washing and Sanitizing Methods for Disinfection of FreshFruit and Vegetable Product. www.ftb.pbf.hr/import/39-4-5.pdf. Diakses tanggal 14 April 2014

Zaenab.2008.Kasus keracunan makanan. http://keslingmks.wordpress.com/2008/12/26/makalah-tentang-kasus-keracunanmakanan/.Diakses tanggal 02 April 2014 